\title{
c.mom \\ Occurrence of the South American Tomato Leaf Miner, Tuta absoluta (Meyrick) in Southern Shan, Myanmar
}

\author{
Sopana Yule ${ }^{1}$, Ni Ni Htain ${ }^{2}$, Aung Kyaw Oo ${ }^{2}$, Paola Sotelo-Cardona ${ }^{3} \mathbb{C}$ and Ramasamy Srinivasan ${ }^{3, *}$ (I) \\ 1 World Vegetable Center, Kamphaeng Saen Campus, East and Southeast Asia Research and Training Station \\ Kasetsart University, Nakhon Pathom 73140, Thailand; sopana.yule@worldveg.org \\ 2 Plant Protection Division, Department of Agriculture, Ministry of Agriculture, Livestock and Irrigation, \\ Yangon 11011, Myanmar; ninihtain@gmail.com (N.N.H.); aungkyaw.flower@gmail.com (A.K.O.) \\ 3 World Vegetable Center, Shanhua, Tainan 74151, Taiwan; paola.sotelo@worldveg.org \\ * Correspondence: srini.ramasamy@worldveg.org; Tel.: +886-(0)-6583-7801
}

Citation: Yule, S.; Htain, N.N.; Oo, A.K.; Sotelo-Cardona, P.; Srinivasan, R. Occurrence of the South American Tomato Leaf Miner, Tuta absoluta (Meyrick) in Southern Shan, Myanmar. Insects 2021, 12, 962. https://doi.org/10.3390/ insects12110962

Academic Editor: Lara Maistrello

Received: 9 September 2021

Accepted: 19 October 2021

Published: 22 October 2021

Publisher's Note: MDPI stays neutral with regard to jurisdictional claims in published maps and institutional affiliations.

Copyright: (c) 2021 by the authors. Licensee MDPI, Basel, Switzerland. This article is an open access article distributed under the terms and conditions of the Creative Commons Attribution (CC BY) license (https:// creativecommons.org/licenses/by/ $4.0 /)$.

Simple Summary: Tomato is the most important vegetable grown in Myanmar. However, its production is threatened by the invasion of the new insect pest, the South American tomato leaf miner, Tuta absoluta. Preliminary surveys on pest occurrence on tomato crops in Myanmar suggested the presence of T. absoluta in Southern Shan State, but there was no official survey conducted until the end of 2019. Therefore, this study aimed to confirm the presence of T. absoluta in Myanmar. Tuta absoluta presence was confirmed in all fields and locations surveyed in Myanmar, under two cultivation methods, (i.e., floating-and land cultivation). Higher infestation levels recorded at theKalaw location (land cultivation) seemed to correspond with plants at flowering and early harvesting stages. Moreover, information collected from the survey showed that the amount of T. absoluta larvae was significantly higher in the lower third of the plants followed by the middle section and upper section, respectively, in three fields of the survey.

Abstract: The South American tomato leaf miner, Tuta absoluta (Meyrick) (Lepidoptera: Gelechiidae), one of the most important invasive insect pests affecting tomato production worldwide, was for the first time detected in Myanmar. Preliminary surveys on pest occurrence on tomato crops in Myanmar suggested the presence of T. absoluta in Southern Shan State, but there was no official survey conducted until the end of 2019. Therefore, this study aimed to confirm the presence of T. absoluta in Myanmar. The presence of T. absoluta was specifically observed in the Southern Shan State, which is the largest tomato production area in Myanmar, where tomato is grown under two cultivation methods, floating and land cultivation. The highest T. absoluta infestation was recordedat Kalaw with (82\%), followed by Inle Lake (i.e., floating cultivation) $(20 \%)$ and Pin Ta Ya (10\%). The amount of T. absoluta larvae was significantly higher in the lower third of the plants, followed by the middle section and upper section, respectively, in three fields surveyed. Potential and severe economic damage may be expected if management practices are not in place to reduce the presence of this invasive pest. It is of immediate importance that plant protection and quarantine offices of ASEAN member states coordinate their response to T. absoluta and build their capacity to monitor the pest and develop a strategy for when it arrives. In addition, a suitable management strategy is needed to reduce the occurrence of this invasive pest.

Keywords: Tuta absoluta; Inle Lake; land cultivation; floating tomato cultivation; Southeast Asia

\section{Introduction}

Tomato is the most important vegetable grown in Myanmar, with three times more area harvested compared to the second and third vegetable crops, mustard and cabbage, respectively [1]. The production in Myanmar occupied over 112,000 ha and $15 \mathrm{t} / \mathrm{ha}$ productivity in 2015-2016, with the major cultivation areas located in Sagaing Division, Magway Division, Mandalay Division and Shan State. Southern Shan State is one of the 
important tomato production areas in Myanmar, with over 6000 ha [2]. In Shan State, tomatoes are grown under two different cultivation methods, viz., floating- and land cultivation, with a large wholesale market of tomato located at Inle Lake. Despite the large harvested area, tomato yields are one-third of the world average [1]. In general, the presence of insect pests and diseases constrain tomato production worldwide. The South American tomato leaf miner, Tuta absoluta (Meyrick) (Lepidoptera: Gelechiidae) is one of the most important invasive insect pests affecting tomato production worldwide in the recent decade [3]. T. absoluta is native to Peru in South America and since early 2000s, it has spread through the rest of America, Africa, Europe and Asia. In 2014, the presence of T. absoluta was officially registered in two states of India [4]. Subsequently, Bangladesh, Nepal, and several countries in Central Asia had also reported the presence of this pest. In contrast, detections of this insect have not been announced in North America and some parts of Asia such as Cambodia, Japan, Laos, Indonesia and Thailand [5-9]. To the best of our knowledge, there are no official reports of T. absoluta presence in most Southeast Asian countries $[9,10]$. However, since T. absoluta has been already detected throughout India and Central Asia, there is a high possibility that sooner or later this pest will spread across borders to tomato production areas in Southeast Asian countries. Tuta absoluta larva feeds on the mesophyll of aerial parts of the plant and creates mine blotches on leaves, stems, buds and fruits [11,12]. This insect feeds primarily on tomato (Solanum lycopersicum L.), but other solanaceous and non-solanaceous crops including potato (Solanum tuberosum L.), eggplant (Solanum melongena L.), melon pear (Solanum muricatum Aiton), spinach (Spinacia oleracea L.), alfalfa (Medicago sativa L.), beet (Beta vulgaris L.), watermelon (Citrullus lanatus (Thunberg) Matsumura \& Nakai) and common bean (Phaseolus vulgaris L.) can also serve as secondary hosts [13-15]. If management strategies are not in place, direct economic losses can be up to $80-100 \%$ on tomato production $[14,16]$.

Preliminary surveys on pest occurrence on tomato production in Pin Ta Ya and Nyaungshwe, Myanmar, conducted by the Plant Protection Division (PPD) in 2017-2018 suggested the presence of T. absoluta in Southern Shan State, but there was no official survey conducted until the end of 2019. Therefore, this study aimed to confirm the presence of T. absoluta in Myanmar, and then to evaluate the influence of floating- and land cultivation of tomatoes on T. absoluta infestation levels in Southern Shan State. Information provided in this study will help in confirming the presence of T. absoluta in the region and assist in the development of plant protection and quarantine strategies to coordinate the response to reduce the spread and infestation of T. absoluta.

\section{Materials and Methods}

\subsection{Survey Location}

Three locations in different cultivation regions in Southern Shan State, Myanmar, were surveyed for the presence of T. absoluta in December 2019. One of the locations, Nyaungshwe, is known for having a floating cultivation method, whereas, the other two locations-Kalaw and Pin Ta Ya-have a conventional land cultivation method (Table 1). Within each location, three fields were selected and surveyed for T. absoluta infestation percentage and population density. To determine the infestation percentage, 20 plants in each field were randomly selected; plants were in different developmental stages, comprising flowering stage (35-40 days), early harvesting stage (3.5 months) and last harvesting stage (4-5 months). Number of damaged leaflets and total number of leaflets were recorded. In addition, the number of larvae and mine blotches per leaf were counted on three leaflets from upper, middle and lower strata of the plant. The leaf infestation percentage was calculated as:

$$
\text { Leaf infestation }(\%)=[(\text { No. of infested leaves } / \text { total No. of leaves }) \times 100]
$$


Table 1. Tomato sampling sites used during Tuta absoluta survey atthree locations and two cultivation methods in the South Shan State in Myanmar.

\begin{tabular}{|c|c|c|c|c|c|c|}
\hline Cultivation & Location & Field & Villages & $\begin{array}{c}\text { GPS } \\
\text { Coordinates }\end{array}$ & Plant Stage & Variety/Type \\
\hline \multirow{3}{*}{$\begin{array}{l}\text { Floating } \\
\text { cultivation }\end{array}$} & \multirow{3}{*}{$\begin{array}{c}\text { Inle Lake } \\
\text { Nyaung- } \\
\text { shwe }\end{array}$} & 1 & $\begin{array}{c}\text { Nga Phe Chaung } \\
0.14 \text { ac }\end{array}$ & $\begin{array}{l}\mathrm{N} 20^{\circ} 31^{\prime} 1^{\prime \prime} \\
\mathrm{E} 96^{\circ} 53^{\prime} 59^{\prime \prime}\end{array}$ & $\begin{array}{l}\text { Late harvesting } \\
\text { stage ( } 5 \text { months) }\end{array}$ & $\begin{array}{c}\text { Princess } \\
\text { (hybrid)/indeterminate }\end{array}$ \\
\hline & & 2 & Za Yiet Gyi 0.08 ac & $\begin{array}{l}\mathrm{N} 20^{\circ} 28^{\prime} 53^{\prime \prime} \\
\mathrm{E} 96^{\circ} 54^{\prime} 26^{\prime \prime}\end{array}$ & $\begin{array}{l}\text { Late harvesting } \\
\text { stage (4 months) }\end{array}$ & $\begin{array}{c}\text { Princess } \\
\text { (hybrid)/indeterminate }\end{array}$ \\
\hline & & 3 & Kay Lar 0.08 ac & $\begin{array}{l}\mathrm{N} 20^{\circ} 30^{\prime} 10^{\prime \prime} \\
\mathrm{E} 96^{\circ} 55^{\prime} 0^{\prime \prime}\end{array}$ & $\begin{array}{l}\text { Late harvesting } \\
\text { stage (4 months) }\end{array}$ & $\begin{array}{c}\text { Princess } \\
\text { (hybrid)/indeterminate }\end{array}$ \\
\hline \multirow{3}{*}{$\begin{array}{c}\text { Land } \\
\text { cultivation } 1\end{array}$} & \multirow{3}{*}{ Kalaw } & 1 & - & $\begin{array}{l}\mathrm{N} 20^{\circ} 35^{\prime} 17^{\prime \prime} \\
\mathrm{E} 96^{\circ} 36^{\prime} 31^{\prime \prime}\end{array}$ & $\begin{array}{l}\text { Last harvesting } \\
\text { stage (5 months) * }\end{array}$ & unknown/indeterminate \\
\hline & & 2 & $1.00 \mathrm{ac}$ & $\begin{array}{l}\mathrm{N} 20^{\circ} 33^{\prime} 17^{\prime \prime} \\
\mathrm{E} 96^{\circ} 36^{\prime} 44^{\prime \prime}\end{array}$ & $\begin{array}{c}\text { Early harvesting } \\
\text { stage (3.5 months) }\end{array}$ & $\begin{array}{c}909 \\
\text { (hybrid)/indeterminate }\end{array}$ \\
\hline & & 3 & Aung Ban ${ }^{\mathrm{a}} 0.10 \mathrm{ac}$ & $\begin{array}{l}\mathrm{N} 20^{\circ} 40^{\prime} 43^{\prime \prime} \\
\mathrm{E} 96^{\circ} 41^{\prime} 15^{\prime \prime}\end{array}$ & $\begin{array}{l}\text { Flowering stage } \\
\text { (35-40 days) }\end{array}$ & $\begin{array}{l}\text { cherry tomato } \\
\text { (hybrid)/determinate }\end{array}$ \\
\hline \multirow{3}{*}{$\begin{array}{c}\text { Land } \\
\text { cultivation } 2\end{array}$} & \multirow{3}{*}{ Pin Ta Ya } & 1 & Zaw Gyi 0.50 ac & $\begin{array}{l}\mathrm{N} 20^{\circ} 59^{\prime} 29^{\prime \prime} \\
\mathrm{E} 96^{\circ} 40^{\prime} 1^{\prime \prime}\end{array}$ & $\begin{array}{c}\text { Late harvesting } \\
\text { stage ( } 4.5 \text { months) }\end{array}$ & $\begin{array}{c}909 \\
\text { (hybrid)/indeterminate }\end{array}$ \\
\hline & & 2 & Zaw Gyi 1.30 ac & $\begin{array}{l}\text { N } 20^{\circ} 59^{\prime} 16^{\prime \prime} \\
\text { E } 96^{\circ} 39^{\prime} 57^{\prime \prime}\end{array}$ & $\begin{array}{l}\text { Late harvesting } \\
\text { stage ( } 5 \text { months) }\end{array}$ & $\begin{array}{c}909 \\
\text { (hybrid)/indeterminate }\end{array}$ \\
\hline & & 3 & Zaw Gyi 0.20 ac & $\begin{array}{l}\mathrm{N} 20^{\circ} 59^{\prime} 12^{\prime \prime} \\
\mathrm{E} 96^{\circ} 39^{\prime} 49^{\prime \prime}\end{array}$ & $\begin{array}{c}\text { Flowering stage } \\
\text { (35 days) }\end{array}$ & $\begin{array}{c}909 \\
\text { (hybrid)/indeterminate }\end{array}$ \\
\hline
\end{tabular}

* Severely infected by late blight; ${ }^{\text {a }}$ GAP farm; ${ }^{\text {a }}$ ac $=$ acreage.

\subsection{Statistical Analysis}

Statistical analysis was performed for the number of larvae and mine blotches data in order to determine T. absoluta oviposition preferences on upper, middle and lower leaflets within a plant for each field and location surveyed. To adjust data as normal distribution, data was square-root transformed (sqrt $x+0.5$ ), and later analyzed using Proc GLM of SAS, version 9.4 (SAS Institute, Cary, NC, USA). Non-transformed means are used in the tables. Furthermore, correlations between T. absoluta larvae and mine blotches were calculated using the procedure Proc CORR of SAS version 9.4 (SAS Institute, Cary, NC, USA) for different plant positions (upper, middle and lower section of the plants) and across locations and fields in order to have general information for the prediction of T. absoluta presence based on mine blotches or vice versa.

\section{Results}

\subsection{Tuta absoluta Survey}

Tuta absoluta was recorded in Southern Shan State in December 2019 (Figures 1 and 2). This state is the largest tomato production area in Myanmar, where tomato is grown under two different cultivation methods-floating- and land cultivation. The floating cultivation is typically found at Inle Lake, Nyaugshwe, where farmers grow tomato year-round. Tomato plants in the selected fields were found in different stages including flowering, early harvesting and late harvesting stages. The highest infestation was recorded for Kalaw (i.e., land cultivation 1 ) with $82 \%$ infestation, followed by Inle Lake (i.e., floating cultivation), with $20 \%$ infestation, and Pin Ta Ya (i.e., land cultivation 2), with $10 \%$ infestation (Table 2).The two highest infestation levels were recorded at the Kalaw location for early harvesting plants (approx. 3.5-month-old plants), followed by flowering stage plants (approx. 35-45-day-old plants) in fields 2 and 3, respectively (Table 2).The lowest infestation levels (5\%) were observed at the Pin Ta Ya location (all three fields) for plants in early flowering (approx. 35-day-old plants) and late harvesting (4.5-5-month-old plants) stages 
(Table 2). In addition, late harvesting plants (4-month-old plants) in field 3 of Inle Lake also sustained low level infestations.

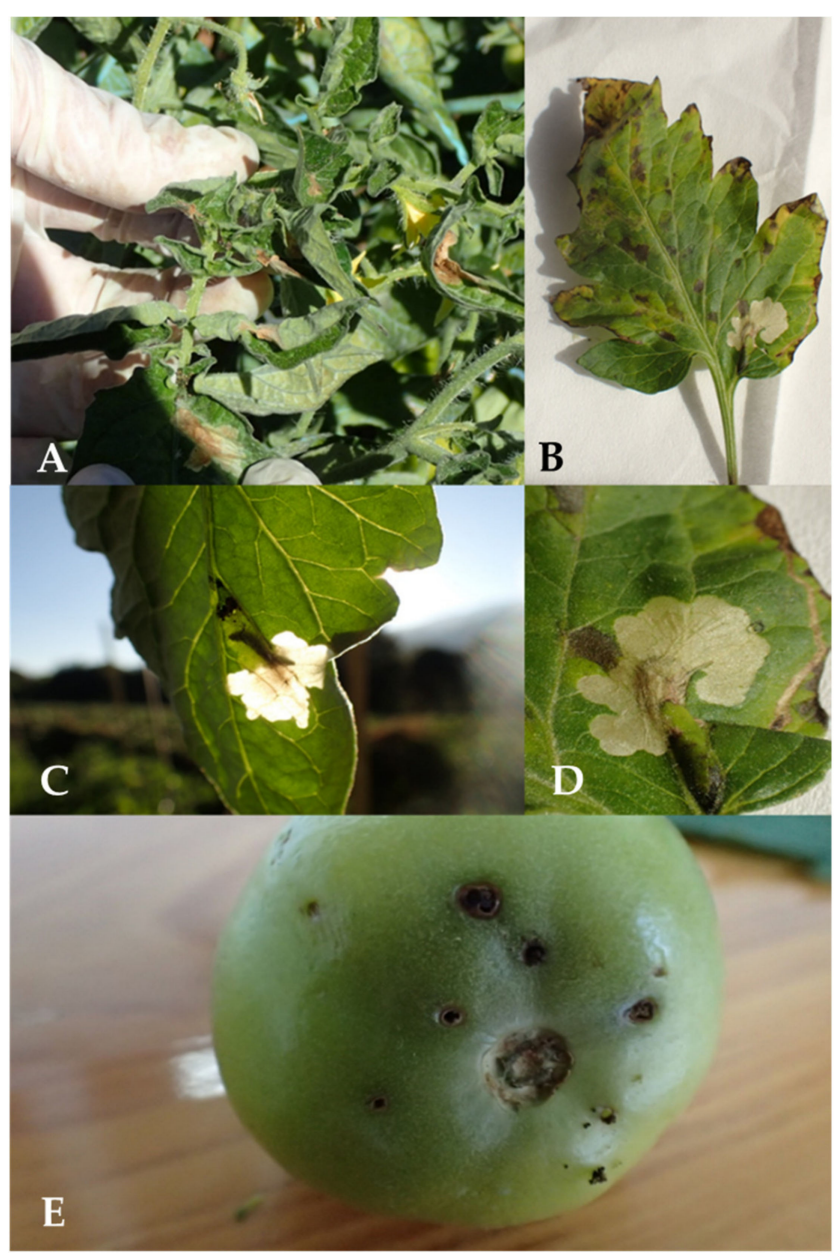

Figure 1. Typical damage on tomato leaves (A-D) and fruits (E) caused by the larvae of Tuta absoluta.
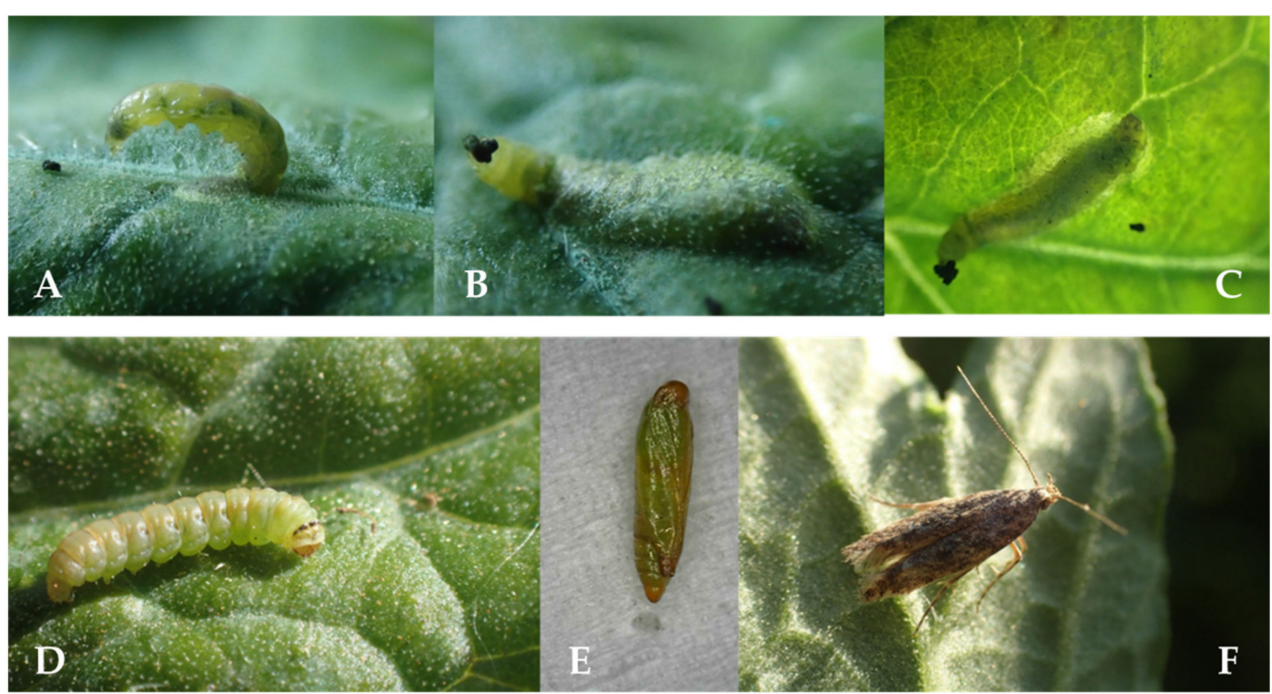

Figure 2. Tuta absoluta development stages: larva (A-D), pupa (E) and adult (F). Details of larval mining under leaf surface on A-C. 
Table 2. Mean Tuta absoluta infestation level and number of mine blotches per tomato leaflet at three locations under two different cultivation methods.

\begin{tabular}{|c|c|c|c|c|c|c|}
\hline Cultivation & Location & Field & $\mathbf{N}$ & $\begin{array}{l}\text { Mean Infestation ( } \pm \text { SE) } \\
\text { (\%) (Min-Max Range) }\end{array}$ & $\begin{array}{c}\text { Mean Number of } \\
\text { Larvae }( \pm \text { SE) } \\
\text { (Min-Max Range) }\end{array}$ & $\begin{array}{l}\text { Mean Number of } \\
\text { Mines/Leaf ( } \pm \text { SE) } \\
\text { (Min-Max Range) }\end{array}$ \\
\hline \multirow{3}{*}{ Floating cultivation } & \multirow{3}{*}{$\begin{array}{l}\text { Inle Lake } \\
\text { Nyaungshwe }\end{array}$} & 1 & 20 & $19.91 \pm 3.85(0-67)$ & $0.00 \pm 0.00(0-0)$ & $4.75 \pm 0.66(1-13)$ \\
\hline & & 2 & 20 & $13.34 \pm 2.64(0-33)$ & $0.35 \pm 0.11(0-1)$ & $2.00 \pm 0.41(0-6)$ \\
\hline & & 3 & 20 & $6.96 \pm 2.42(0-45)$ & $1.35 \pm 0.58(0-11)$ & $4.60 \pm 1.87(0-35)$ \\
\hline \multirow{3}{*}{ Land cultivation 1} & \multirow{3}{*}{ Kalaw } & 1 & 20 & $15.91 \pm 2.71(0-36)$ & $2.70 \pm 1.13(0-16)$ & $4.75 \pm 1.63(0-27)$ \\
\hline & & 2 & 20 & $81.59 \pm 5.28(31-100)$ & $14.35 \pm 1.72(1-29)$ & $34.00 \pm 3.15(17-70)$ \\
\hline & & 3 & 20 & $41.89 \pm 5.49(7-91)$ & $5.35 \pm 0.93(0-14)$ & $6.90 \pm 1.00(1-17)$ \\
\hline \multirow{3}{*}{ Land cultivation 2} & \multirow{3}{*}{ Pin Ta Ya } & 1 & 20 & $5.73 \pm 1.94(0-31)$ & $0.45 \pm 0.20(0-3)$ & $2.25 \pm 0.70(0-9)$ \\
\hline & & 2 & 20 & $9.82 \pm 3.03(0-61)$ & $0.50 \pm 0.15(0-2)$ & $1.65 \pm 0.42(0-7)$ \\
\hline & & 3 & 20 & $5.11 \pm 1.67(0-29)$ & $0.75 \pm 0.32(0-6)$ & $2.35 \pm 0.78(0-12)$ \\
\hline
\end{tabular}

In line with the infestation levels, the highest number of larvae and mines were also observed in fields 2 and 3 at the Kalaw location (Table 2). Infestation levels and number of mine blotches were also consistent across regions, with Kalaw presenting four- and seven-times higher number of mines compared to Inle Lake and Pin Ta Ya, respectively (Table 2).

\subsection{Tuta absoluta Leaflet Preferences}

Information collected during the survey was used to recognize potential preferences of T. absoluta in terms of leaf positions (i.e., upper third, middle third or lower third of the plant). The number of T. absoluta larvae was significantly higher in the lower third of the plant followed by the middle section and upper section, respectively, in three fields of the survey (i.e., field 3 Inle Lake $\left(\mathrm{F}_{2,59}=3.19 ; p=0.0487\right)$, field 3 Kalaw $\left(\mathrm{F}_{2,59}=4.25 ; p=0.0191\right)$ and field 3 Pin Ta Ya $\left(\mathrm{F}_{2,59}=5.09 ; p=0.0093\right)$ ) (Figure 3A). Similarly, the amount of mine blotches found in the lower section of the plant was higher compared to those recorded in the middle and upper section, respectively, in four fields of the survey (i.e., fields 1 $\left(\mathrm{F}_{2,59}=5.79 ; p=0.0051\right)$ and $3\left(\mathrm{~F}_{2,59}=4.61 ; p=0.0139\right)$ of Inle Lake, field 3 Kalaw $\left(\mathrm{F}_{2,59}=4.96\right.$; $p=0.0103)$ and field 3 Pin Ta Ya $\left(\mathrm{F}_{2,59}=4.61 ; p=0.0139\right)$ ) (Figure 3B).

The correlations between T. absoluta larvae and mine blotches across field and locations were highly significant for all three plant strata. The correlation values between the two factors in the upper leaves was $\mathrm{r}=0.8996 ; p<0.0001 ; n=180$; middle section: $\mathrm{r}=0.8389$; $p<0.0001 ; n=180$; and lower section: $\mathrm{r}=0.7896 ; p<0.0001 ; n=180$. 

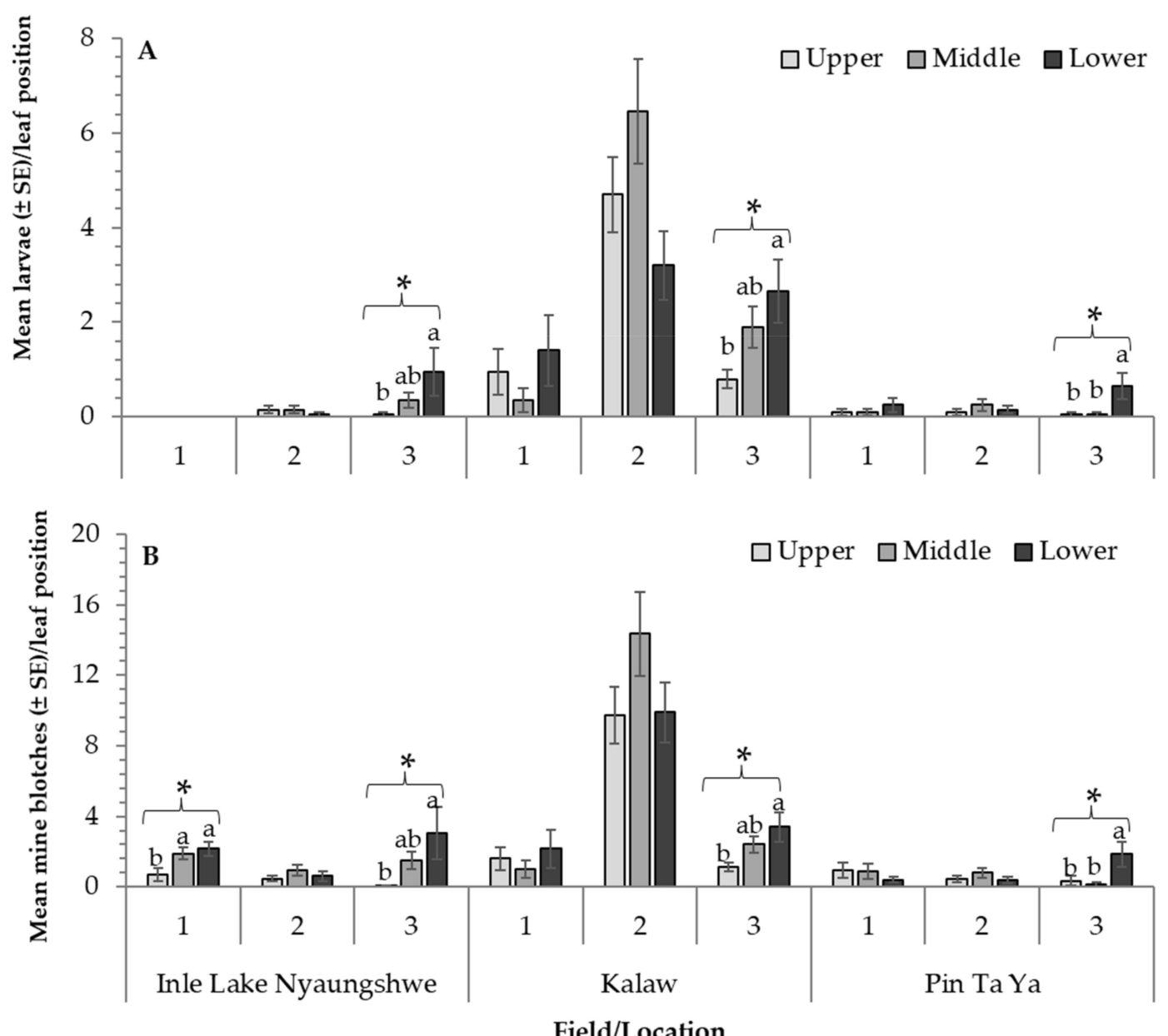

Field/Location

Figure 3. (A) Mean Tuta absoluta larvae and (B) mine blotches found on upper, middle and lower strata recorded in three locations and two tomato cultivation methods in Myanmar. * Statistical values provided for the locations where Tuta absoluta larvae and mine blotches differed among leaf position. Bars with the same letter(s) within each field/location are not significantly different $(p<0.05)$ (See text for statistical details).

\section{Discussion}

This survey confirmed the presence of Tuta absoluta in all fields and locations surveyed in Myanmar, and under two cultivation methods, (i.e., floating- and land cultivation). Furthermore, higher infestation levels recorded at the Kalaw location seemed to correspond with plants at flowering and early harvesting stages. High infestation levels indicate a potential of severe economic damage if management practices are not initiated in a timely manner to reduce the occurrence of this invasive insect pest. According to Diatte et al. (2018) [17], T. absoluta starts to colonize on tomato just after transplanting at vegetative stage and reaches a maximum infestation during the flowering-fruiting stages, with $87.50 \%$ infestation detected in early fruiting stage, followed by early flowering-, vegetative- and harvesting stages. In line with this, Allache et al. (2015) [18] indicated that the number of T. absoluta eggs and larvae were very low in early vegetative stage but increased in late harvest stages. Our observation was also in agreement with Abdelhady et al. (2020) [19], who found that the attraction of T. absoluta to tomato plants varied with the age of the plants, with high percentages of attraction associated with the 30- and 45-day-old plants. Additionally, we also observed that most tomato plants in Nyaungshwe and Pin Ta Ya at late harvesting stage were severely infected by diseases such as late blight (Phytophthora infestans) and leaf spot (Corynespora cassiicola) [20]. We believe that given the disease 
prevalence, T. absoluta moths might have preferred to choose healthy plants or may also have preferred young plants for oviposition, but this hypothesis requires further validation.

The number of T. absoluta larvae was significantly higher in the lower stratum of the plant, followed by the middle stratum and upper stratum, respectively, in three fields of the survey. Previous studies have found that T. absoluta females laid their eggs on the upper and middle strata of the plants, and as the plants grow, the larvae is then found in the lower and middle strata of the plant, as the infested tissues were part of the upper and middle parts of the plant [21,22]. With the information gathered during the survey, we also found high correlation between the number of mine blotches and larvae across fields, locations and for all plant sections evaluated. This information is important in terms of monitoring the presence of T. absoluta in the fields, as any sections surveyed will provide strong correlation between damage and larval presence. The presence of more mines than larvae has also been discussed in previous papers, suggesting that as larvae grow older, they may need to seek for younger tissues, and consequently, more than one mine can be created by the same individual [22]. However, as previously presented, older plants may yield lower infestation levels compared to those in early stages (i.e., flowering and early harvesting stages). Hence, in order to reduce damaging effects of T. absoluta during flowering and fruiting stages, the use of integrated pest management strategies is needed to reduce the damage of this invasive pest in Myanmar. Furthermore, it is highly imperative that plant protection and quarantine officers of Association of Southeast Asian Nations (ASEAN) member states coordinate their response to T. absoluta and build their capacity to monitor this pest and be prepared with suitable integrated pest management strategies when the pest arrives in their region(s).

Author Contributions: Conceptualization, N.N.H., R.S., S.Y. and P.S.-C. Methodology, P.S.-C. and S.Y.; Software, P.S.-C. and S.Y.: validation, N.N.H., R.S., S.Y., P.S.-C.; formal analysis, S.Y. and P.S.-C.; investigation, N.N.H. and S.Y.; resources, A.K.O. and N.N.H.; data curation, N.N.H., R.S., S.Y. and P.S.-C.; writing—original draft preparation; S.Y. and P.S.-C.; writing—review and editing; A.K.O., N.N.H., P.S.-C., R.S. and S.Y.; visualization; P.S.-C.; supervision, R.S.; project administration, R.S.; funding acquisition, R.S. All authors have read and agreed to the published version of the manuscript.

Funding: This study was financed by the World Vegetable Center, Taiwan, and by long-term strategic donors to the World Vegetable Center: Taiwan, Foreign, Commonwealth \& Development Office (FCDO) from the UK government, United States Agency for International Development (USAID), Australian Centre for International Agricultural Research (ACIAR), Germany, Thailand, Philippines, Korea and Japan.

Institutional Review Board Statement: Not applicable.

Informed Consent Statement: Not applicable.

Data Availability Statement: The data presented in this study are available on request from the corresponding author. The data can be accessed from https:/ / worldveg.tind.io/.

Acknowledgments: We would like to show our gratitude to the Department of Agriculture, Ministry of Agriculture, Livestock and Irrigation, Yangon, Myanmar, for approval of detection of Tuta absoluta in Southern Shan Stateand assistance on organizing field survey and data collection.

Conflicts of Interest: The authors declare no conflict of interest.

\section{References}

1. Davis, T.D.; Bost, E.M.; Byce, C.N. Emerging horticultural research and education opportunities in Myanmar. HortScience 2017, 52, 1141-1144. [CrossRef]

2. DOP. Myanmar Agriculture at Glance 2015-2016; Department of Planning, Ministry of Agriculture, Livestock and Irrigation, MOALI: Nay Pyi Taw, Myanmar, 2016.

3. Biondi, A.; Guedes, R.N.C.; Wan, F.H.; Desneux, N. Ecology, worldwide spread, and management of the invasive South American tomato pinworm, Tuta absoluta: Past, present, and future (review). Ann. Rev. Entomol. 2018, 63, 239-258. [CrossRef] [PubMed]

4. CABI. Tuta absoluta. Available online: https://www.cabi.org/isc/datasheet/49260\#todistribution (accessed on 14 February 2020). 
5. Alam, S.N.; Begum, K.; Sarkar, M.A.; Shah, M.M.R.; Mannan, M.A.; Pradhan, M.Z.H.; Islam, M.A.; Rahman, M.Z. First record of the tomato leaf miner, Tuta absoluta (Meyrick) (Lepidoptera: Gelechiidae) in Bangladesh. Bangladesh J. Entomol. 2016, $26,71-76$.

6. Bajracharya, A.S.R.; Mainali, R.P.; Bhat, B.; Bista, S.; Shashank, P.R.; Meshram, N.M. The first record of South American tomato leaf miner, Tuta absoluta (Meyrick 1917) (Lepidoptera: Gelechiidae) in Nepal. J. Entomol. Zool. Stud. 2016, 4, $1359-1363$.

7. Uulu, T.E.; Ulusoy, M.R.; Çalışkan, A.F. First record of tomato leafminerTuta absoluta Meyrick (Lepidoptera: Gelechiidae) in Kyrgyzstan. EPPO Bull. 2017, 47, 285-287. [CrossRef]

8. Saidov, N.; Srinivasan, R.; Mavlyanova, R.; Qurbonov, Z. First report of invasive South American tomato leaf miner (Lepidoptera: Gelechiidae) in Tajikistan. Fla. Entomol. 2018, 101, 147-149. [CrossRef]

9. EPPO. Tuta absoluta. (GNORAB)/Distribution. European and Mediterranean Plant Protection Organization (EPPO) Global Database. Available online: https://gd.eppo.int/taxon/GNORAB/distribution (accessed on 14 February 2020).

10. FAO. Handbook on Climate Smart Agriculture in Myanmar; FAO: Nay Pyi Taw, Myanmar, 2019; p. 192. Available online: http: / / www.fao.org/3/ca3662en/CA3662EN.pdf (accessed on 15 January 2020).

11. Miranda, M.M.M.; Picanço, M.; Zanuncio, J.C.; Guedes, R.N.C. Ecological life table of Tuta absoluta (Meyrick) (Lepidoptera: Gelechiidae). Biocontrol.Sci. Technol. 1998, 8, 597-606. [CrossRef]

12. Cherif, A.; Verheggen, F. A review of Tuta absoluta (Lepidoptera: Gelechiidae) host plants and their impact on management strategies. Biotechnol. Agron. Soc. Environ. 2019, 23, 270-278. [CrossRef]

13. Shashank, P.R.; Chandrashekar, K.; Meshram, N.M.; Sreedevi, K. Occurrence of Tuta absoluta (Lepidoptera: Gelechiidae) an invasive pest from India. Indian J. Entomol. 2015, 77, 323-329. [CrossRef]

14. Desneux, N.; Wajnberg, E.; Wyckhuys, K.A.G.; Burgio, G.; Arpaia, S.; Narváez-Vasquez, C.A.; González Cabrera, J.; Ruescas, D.C.; Tabone, E.; Frandon, J. Biological Invasion of European Tomato Crops by Tuta absoluta: Ecology, Geographic Expansion and Prospects for Biological Control. J. Pest. Sci. 2010, 83, 197-215. [CrossRef]

15. EPPO. Tuta absoluta (GNORAB)/Hosts. European and Mediterranean Plant Protection Organization (EPPO) global database. Available online: https://gd.eppo.int/taxon/GNORAB/hosts (accessed on 14 February 2020).

16. Retta, A.N.; Berhe, D.H. Tomato leaf miner-Tuta absoluta (Meyrick), a devastating pest of tomatoes in the highlands of Northern Ethiopia: A call for attention and action. Res. J. Agric. Environ. Manag. 2015, 4, 264-269.

17. Diatte, M.; Brévault, T.; Sylla, S.; Tendeng, E.; Sall-Sy, D.; Diarra, K. Arthropod pest complex and associated damagein field-grown tomato in Senegal. Int J. Trop. Insect Sci. 2018, 38. [CrossRef]

18. Allache, F.; Bouta, Y.; Demnati, F. Population development of the tomato moth Tuta absoluta (Lepidoptera: Gelechiidae) in greenhouse tomato in Biskra, Algeria. J. Crop. Prot. 2015, 4, 509-517.

19. Abdelhady, M.A.; Sarhan, A.A.; Osman, M.A.M.; Mandour, N.S. Attraction Response of Tuta absoluta Females to Solanaceous Host in Y-Tube Olfactometer. J. Appl. Plant. Prot. 2020, 9, 59-66.

20. International Plant Protection Convention (IPPC). Pests of Tomato in Myanmar. 2015. Available online: https://www.ippc.int/en/ countries/myanmar/pestreports/2015/10/tomato/ (accessed on 10 August 2021).

21. Torres, J.B.; Faria, C.A.; Evangelista, W.S.; Pratissol, D. Within-plant distribution of the leaf miner Tuta absoluta (Meyrick) inmatures in processing tomatoes, with notes on plant phenology. Int. J. Pest. Manag. 2001, 47, 173-178. [CrossRef]

22. Cely, L.; Cantor, F.; Rodríguez, D. Determination of levels of damage caused by different densities of Tuta absoluta populations (Lepidoptera: Gelechiidae) under greenhouse conditions. Agron. Colomb. 2010, 28, 392-402. 